\title{
Dislocated Tripartite Relationship in Nigeria's Industrial Relations
}

\author{
Adenugba, A.A. (Phd) \\ Dept. of Sociology, University of Ibadan \\ Email: bimpeadenugba@yahoo.com \\ Omolawal, S.A (Ph.D) \\ Dept. of Sociology, University of Ibadan \\ Email:omolawal01@yahoo.com
}

\section{Doi:10.5901/mjss.2014.v5n10p704}

\begin{abstract}
This paper examines the dislocated tripartite relationship in Nigeria's Industrial Relations. It traces the trend and pattern of relationship among the three parties in the industrial relations setup viz Government, Employer and Labour from the early 1970s. Historically, this period provided an important watershed in the growth of the Nigerian economy and the increasing intervention of the state in the capital formation process. In seeking to maintain political control while promoting socio-economic development, the government established a central role in the industrial relations system. In the search for new institutions and techniques to facilitate the management of economic development based on state intervention, tripartitism emerged as a vital instrument for consensus building and for ensuring harmonious relations among labour market partners and the government. Enduring tripartism requires the adoption of an ideology of social partnership and manifests readiness by the government to share its authority and responsibility for the management of the economy.
\end{abstract}

Keywords: Tripartism, Industrial Relations, Government, Labour, Employer.

\section{Introduction}

As is now commonly accepted, the 1970s provided an important watershed in the growth of the Nigerian economy and the increasing intervention of the state in the capital formation process. Increased state intervention in the management of the economy, many experts have claimed, creates a need for avoiding legitimacy crisis; in other words, economic crises become political crises and this often erodes the confidence of citizens in the state and its agencies (Adebiyi 1999). In seeking to maintain political control while promoting socio-economic development, governments in most developing societies have established a central role in the industrial relations system. In the search for new institutions and techniques to facilitate the management of economic development based on state intervention, tripartism has emerged as a vital instrument for consensus building and for assuring harmonious relations among labour market partners.

The objectives of this paper are to provide a brief analysis of the concept of tripartism, including the philosophy and objectives which the parties in a tripartite set up seek to realize; to examine practical examples of tripartite relationships and their enhancing factors with a special focus on governance in Nigeria over the years; and to identify some preconditions for a sound tripartite arrangement in Nigeria as a demonstration of the government's genuine commitment to democracy and the rule of law.

\section{Conceptual and Theoretical Frameworks}

Conceptually, tripartism is more than a mere pattern or articulation of interests. In its broader meaning, tripartism is an institutionalized pattern of policy formulation in which the labour market partners cooperate with each other and the state and its agencies are partners in progress not only in the values but in the implementation of agreed policies. The distinguishing feature of matured tripartism is the required intimate, mutual penetration and high degrees of trust and collaboration among the economic and social partners in the sharing of socio-economic policy formulation and implementation.

Tripartism normally exists along side but is often separated from normal collective bargaining. While the latter deals with issues relating directly to wages and conditions of service, the tripartite process would focus on and tackle 
various issues of broader national socio-economic policy, especially those affecting employment and welfare. Instead of confronting each other across the bargaining table with specific demands and threats of sanctions and viewing their interests as fundamentally in conflicts (as in collective bargaining), the social partners seek to tackle what they view as common problems with mutual interest at stake (Crouch 1982).

In this connection, tripartism may be viewed as arrangements which seek to minimize conflict by encouraging the development of problem solving process of industrial relations. Like collective bargaining, tripartism is concerned with organized labour market partners. But unlike collective bargaining, the social partners try to find a positive sum (as opposed to zero sum) gain, that is, looking for points of cooperation where they might both gain something and not simply bargaining over the distribution of a fixed sum of potential gains.

According to Etuk Udo (1999), Government as a partner in industrial relations plays an important role in industrial relations in its capacity of a rule maker. Market forces alone are incapable of promoting equity and social harmony, and the costs of disharmony are high. Industrial relations also have marked non-economic dimensions. The power struggle within the framework of rights and interests disputes also has political overtones. Therefore any acceptability of voluntary interest groups, the institution of collective bargaining as well as the inevitability of industrial conflict, is the result of the stage of development on the democratic path as well as the dominant national ideology.

In its effort to make industrial relations serve the larger purpose of national economic development, most governments adopt a corporatist model of industrial relations. Corporatism relies on trade unions and employers to agree on basic economic and social policies. If they are well organized, both the union and employers can extract concession from government in return for supporting its socio-economic policies. Such an arrangement requires that trade unions restrain their economic power in exchange for a major role in public policy, guarantees of a measure of economic protection for their members, and the adoption of some public policies that benefit workers generally. In a similar vein, employers win a respite from trade union wage pressure, together with the hope or expectation of expanding markets. This is the practice in Germany, France, Japan and other countries. The German industrial relations stability owes to the existence of a national consensus among government, employers and the trade unions which promote national competitiveness through technological superiority.

The Pluralist theory views the society as comprising various interest groups with each pursuing its self interest in different ways. The theory argues that in any society or organization, there are groups with various interests, beliefs and aspirations. Emphasis on pluralism is placed on continuous compromises and concessions between and among the various groups in the society. It stresses the diversity of individuals and group interests and goals. Society is perceived as a coalition of plural interest groups held together in some sort of balance and equilibrium by the agency of the state. Pluralism according to Clegg (1975) is self consistent- its theme is that men associate together to further their common interests and desires; their association exerts pressure on each other and on the government; their concessions which follow help to bind society together; thereafter stability is maintained by further concessions and adjustments as new associations emerge and power shifts from one group to another.

Given the multiplicity of various interest groups and the interactive environment, conflict becomes inevitable, but need not be forbidden. Rather it should be recognized and managed for the overriding benefit of all. According to Ross (1985), the problem of government in a plural society is not to unify, integrate or liquidate sectional groups and their special interests in the name of some overriding corporate existence, but to control and balance the activities of constituent parts. This idea is captured further by Ralf Dahrendorf (1959) that recognition of conflicting interests should logically lead to a systematic settlement; hence resolution of conflict becomes institutionalized.

Relating this theoretical framework to the tripartite relationship in Nigeria, we can see that the theory serves as the starting point for understanding the industrial relations and tripartite arrangement in Nigeria. Nigeria is a pluralist nation, and the labour policy, which determines labour-management relations and labour -management-government relations are based on this ideology. The government, the employers and the labour form the three stands of the tripartite relationship. The idea is that each of them has its peculiar and defined role to play in engendering and promoting peace in industrial set up as well as in the nation as a whole. The issues of industrial democracy, tripartism, joint negotiation, productivity bargaining and collective bargaining are all pluralist ideologies.

\section{Tripartism in Nigeria's Industrial Relations System}

A dominant feature of both the advanced and developing economies today is that economic policy has become more and more dependent upon a process of consensus building. The latter is largely contingent on the degree to which labour market partners, especially labour are integrated into the policy formulation processes. The deficiencies of self regulation by laissez-faire economies have placed the burden of evolving such consensus building process on the state. In the 
developing economies such as Nigeria, the status of the state can be viewed as a mega force; it is the strategic gatekeeper determining who has access to key resources and its actions affect all others or stakeholders in the business of government and government of business. Thus as a vital component of state intervention strategy, tripartism has an objective of organizing, mobilizing and winning the collaboration of labour market partners in the formulation and implementation of socio-economic development programmes. Tripartism eliminates controversial policies which may impede pursuit of development oriented objectives by the labour market partners and government, thus minimizing the risk of social disruption.

A second objective of the state in extending participation to social partners is to seek to reduce areas of conflicts with labour unions and employers by taking them into tripartite structures in which they could be persuaded to cooperate and adopt the views of government and capital on broader economic priorities. A review of literature indicates that with trade union participation in tripartite structures, capital growth criteria, avoidance or management of inflation and other macro-economic considerations have entered into formulation of wage policies.

Thirdly, the involvement of unions and employer enables them to exercise some influence within many areas from which they had previously been excluded; it gives them access to relevant information on the workings of the political economy and brings a new stature and acceptance of their position in society. The objectives of the employers which are not too different from those of government and the union include the desire to protect their dominant power position in the capital accumulation process and play an active role in the national development process (Damachi 1987)

Incomes policy is one field in which tripartite arrangements have been most conspicuous. In virtually all economies in which tripartism has become an important instrument, incomes policy, designed to abate the wage pressures of trade unions, has always been the front piece of tripartite development. As the main domain of tripartism therefore, incomes policy serves the function of integrating labour market partners, particularly labour unions, into economic decision making and implementation.

In Nigeria for example, this integration was reflected in the constitution of the membership of the National Productivity, Price and Incomes Board (NPPIB) established by Decree 30 of 1976. As a tripartite body, the NPPIB consisted of four (4) representatives each of labour and employers and twelve (12) representatives of government and other stakeholders. Among the principal objectives which the government sought to achieve in its income policies were cost and price stabilization; equitable incomes distribution, reform of the wage determination process and productivity and economic growth. Up till 1988, Nigeria witnessed a regime of wage control policy, ostensibly intended to complement other macro economic policies. (Fashoyin 1984)

As an institutional framework for consensus building, it facilitates the clearing and adjustments of divergent interests on the overall goals of public economic policy among social partners. The crucial point to note is that conflicting views among the labour partners can be negotiated and agreed at the level of the board, thereafter partners are expected to ensure compliance among their members. Policies are thereby developed. Through the NPPIB in Nigeria, therefore, the state was placed in a position to subordinate the interests of labour market partners to national socio-economic priorities.

Another manifestation of tripartism in practice was the creation of strong trade unions with specific structural characteristics of centralization and concentration. These principles of organization are also required of employers' organizations, though they are of more vital importance in the case of organized labour. In Nigeria, the Nigerian Employers' Consultative Association (NECA) is known to have voluntarily re-organized its structure in line with the industrial structure of trade union movement. The Trade Union Decrees No 21 and 22 of 1978 re-structured trade union on the principles of industry wide organization (concentration) and the 42 (now 29) industrial unions were brought under the compulsory influence of the Nigerian Labour Congress (centralization). Both principles made the relationships among labour market partners smooth thus reducing incidents of conflicts. Empirical evidence from other countries, such as the UK show that lack of both conditions and a large measure of rank and file autonomy, especially if combined with plant level bargaining, tend to impair severely the capacity of labour market partners.

The existence of well defined legal framework for collective bargaining is also a facilitating factor for tripartite relationships. A well defined legal framework normally establishes a suitable condition for uniform application of agreed guidelines. To a considerable extent, these conditions were provided for in the Nigerian tripartite arrangement by the Trade Unions Dispute Decrees No 7 and 23 both of 1976. Both decrees have provided the pillars of the framework for collective bargaining and dispute settlement. Most importantly, such a framework facilitates the channeling of unresolved and difficult disputes into tripartite institutions such as Industrial Arbitration Panel and National Industrial Court. Affirming this is Dublin (1954) who claims that the existence of conflicts of interests in industry is scarcely questionable; that we have institutionalized the mode of this conflict through collective bargaining is also clear. We have thus built in, in the institutional practice of collective bargaining, a social device for bringing conflict to a successful resolution. 


\section{Dislocation of Tripartite Relationship}

Dislocation in the context of this paper refers to the gradual shift from cooperative relationship to unilateralism and suppression on the part of the government. Two major factors have been identified as being responsible for this dislocation viz; economic depression necessitating reform programmes, coupled with the ideology of the government.

Signs of dislocation started to emerge following the depression years since the 1980s and this poisoned the climate for labour - management - government cooperation. Few things weaken the strength of organized labour more than a high level of or threat of unemployment. The economic crisis since 1980s has served to weaken trade unions' bargaining power. Consequently, there has been a discernible swing away from cooperative relations towards labour exclusionism on the part of the government. In Nigeria, this policy thrust (labour exclusionism) which became pronounced during the Buhari administration developed into a frightening anti-labour posture under the Abacha administration and surprisingly turned into a monster during Obasanjo's democratic governance. The economic depression necessitating reform programmes starting from the Structural Adjustment Programmes of the Babangida era led to the total collapse of tripartite relationships as governments opted to take most decisions without reference to the labour or employers who are social partners in the tripartite arrangement. The dislocation of course created tensions and outright confrontation which affected the peace of the nation.

For example, since the Buhari era, not only has the NPPIB practically ceased to function as a machinery of tripartite approach to economic management, but government became extremely unilateral in its conduct of industrial relations- unwilling to use dialogue or tripartite methods for adjusting conditions of employment.

Also, unilateralism dominated Babangida's SAP relief package and the compulsory deductions from all salaries without previous discussions with affected workers and unions under the 1985 National Economic Recovery Fund or the States (Special Development Levies) Decree No 37 of 1986 which empowered government to levy and deduct money from salaries. Collective bargaining was equally deregulated in 1991 under Babangida's regime. These were all clear departures from the philosophy of tripartite incomes policies which has been rendered moribund and irrelevant since that period.

Tripartism witnessed concerted frustrations under the Abacha regime. During this period, notorious Decrees Nos 4 , 26 and 29 were enacted which had serious implications for the labour movement. Officials of PENGASSAN, NUPENG and NLC were at various times dissolved and arrested. Cooperation among labour market partners was practically nonexistent.

The democratic regime of Obasanjo did not bring any succor to the NLC or other labour market partners; neither did it improve the state labour relations. The whole adoption of neo-liberal policies of privatization, deregulation of the petroleum sector among others saw the state and labour in regular conflicts. The government after observing that the NLC on behalf of labour was successful in most of its struggles against the implementation of the neo-liberal policies promulgated the new Trade Union (Amendment) Act 2005 which now limits the power and influence of the NLC. Major highlights of the Act include: de-registration of the NLC as the only central labour organization; insertion of a no-strike clause in the collective bargaining agreements; requirement of a two-third majority vote of all members before a trade union or federation of trade union can embark on a strike action; making of check off dues and union membership to be voluntary. It can therefore be rightly said that a democratic government which the trade union fought to enthrone eventually became its enemy.

A trend common to these successive regimes since early 1980s therefore was a deliberate attempt to discourage tripartite relationship among labour market partners. The tripartite relationship in this era witnessed opposition, coercion, suppression and dictatorship. Not only were legislative frameworks re-defined and reviewed, physical efforts were equally made to suppress and dominate other partners.

The second major factor accounting for the dislocation of the tripartite relationship is the ideology of the leadership which was militarist. In support of this view, Onyeonoru (2001) says that the ideology of those in authority significantly influences their management and industrial relations perspectives- the way they respond to industrial conflicts. The military orientation is to conquer and to destroy anyone or anything they perceive as opposition. This therefore partly accounts for the almost complete neglect of tripartism during the period of administration of Buhari up to the period of Obasanjo.

In fact, what the period of economic crisis seemed to have done has been to heighten the adversarial aspect of the relationship between labour market partners. With respect to the trade unions, the relations with the state became more overtly conflictual while the government became more arbitrary and unilateral in its dealings. In practical terms, virtually all economic packages since 1986 have been imposed by the government with little or no meaningful consultation or input from labour market partners. Adenugba (2006) gives a word of caution and what appears to be a summary, 'as long 
as the state continues to wholesomely adopt the neo-liberal economic policies of globalization which has militarist ideology, there will continue to be conflict, and tripartism will never thrive.'

\section{The Prospects of Tripartism in Nigeria}

Labour organizations are integrated into tripartite structures to give legitimacy to state interventionist policy. Tripartism requires trade unions not to cut their ties with the grass root but rather that they use those ties and linkages to legitimize these policies and reinforce their control over their rank and file members. Here lies the core problem. Since a central aim of tripartite income policy is wage restraint, the burden of which is often borne disproportionately by workers, the application of wage restraint over time has the tendency of alienating labour from state economic policies. This had happened, particularly when tripartism results in the absence of effective trade union input in economic decision making (Martens 1987), absence of extensive prices and profit control and a re-distributive fiscal policy. The neglect of these problems in the long run tends to jeopardize cooperative tripartism. For instance, in a situation where profits and prices run much faster than wages, union leaders would come under heavy pressure from their rank and file members to free them from tripartite chains.

What the above suggests is that the relative stability of tripartite arrangements is largely dependent on what social partners, particularly labour unions, are able to deliver through such forum. Tripartism must be seen as a mutually dependent bargaining relationship in which favourable policy outcomes must be traded for cooperation. The crucial point to note then is that no trade union can cooperate indefinitely in such arrangements without doing something to represent its member's immediate interests, at least in a free society. The identification, defense and advancement of such immediate interests is ultimately the primary reasons for the existence of trade union, and any union that fails to fulfill this primary commitment is vulnerable to challenges from grass root members. Thus to be in a position to deliver their members' consent and support (consensus building), there is a constant need to offer unions and their members something in exchange. This demands that the substantive goal of direct and immediate interests of workers is a permanent item on the agenda of tripartite bodies.

Another important pre-condition for an enduring tripartite arrangement is the readiness of government to move away from the tendencies towards labour exclusionism, arbitrariness or ad-hoc tripartism. For example the Damachi Committee of 1990 (Minimum Wage Committee) set up to examine NLC demand for a review of the national wage of N125.00 per month is a typical example of ad-hoc tripartism. The final decision following such Committee's report was unilateral by the government. Under economic recession and adjustment programmes of successive governments since the early 1980s not only has the relative autonomy of labour market partners, particularly labour union, been eroded, but also arbitrariness and unilateralism have been substituted for consultation between government and other social partners. Tripartism requires a degree of autonomy of labour market partners.

Thirdly, enduring tripartism would require the adoption of an ideology of social partnership and manifest readiness by the government to share its authority and responsibility for the management of the economy. The point can not be overemphasized that responsibility can only be demanded or expected from those to whom responsibility has been given. A share in making socio-economic policy is necessary if social partners are to have genuine confidence that the restraints and concessions which they offer or are being called to offer, are necessary and are being matched by changes elsewhere in society for the same ends of efficiency.

If trade unions are to embrace a tripartite conception of their role by accepting certain responsibilities towards society as well as towards their members then they need to be systematically involved in meaningful consultation and decision making over some basic issues of socio-economic policies. Importantly, they must be empowered to take on this role. It is plausible to argue that it is only through such involvement and participation that labour leaders can be persuaded to conduct industrial relations in a way as would not hold back improvements in the standard of living of the community as a whole. In Nigeria, a resuscitation of the National Labour Advisory Council (NLAC) and the National Productivity, Prices and Incomes Board (NPPIB) will provide the forum for the cultivation of the much needed consensus.

\section{Conclusion}

In the foregoing discussion, attention has been drawn to the concept of tripartism as a means to promote and win the collaboration of labour market partners in the formulation and implementation of socio-economic policies. In this connection, tripartism needs to be viewed as a component of a development oriented industrial relations policy. The underlying philosophy of such a policy is that the only way to promote and sustain collaboration and control over labour market partners is to learn to share such control. Nigeria as a pluralist state stands to benefit greatly from tripartite 
arrangements. This will make policy formulation and implementation easier, social disruptions will be minimized and the citizenry can be guaranteed certain basic benefits such as good standard of living, equitable wages and conditions of service, rule of law, basic infrastructures such as light, water, good roads and so on. Where tripartism is fully embraced, the functioning of the pluralist ideology becomes pronounced and duly recognized as being of immense benefits to all parties in the society.

\section{References}

Adebiyi, A., 1999, Beyond Bargaining: Problems and prospects of Tripartite Relationships in Industrial Relations, in Human Resource Management, a Journal of the Institute of Personnel Management of Nigeria, Vol. 9 No 3, Pp 34-39.

Adenugba, A.A, 2006, Globalization and the Nigerian Labour Congress, (Unpublished PhD Thesis, Dept. of Sociology, University of Ibadan, Ibadan)

Crouch Colin, 1982, Trade Unions: The logic of Collective Action, London: Fontana Paperbacks.

Dahrendorf, Ralf (1959), Class and Class Conflicts in an Industrial Society. London: Routledge \& Kegan Paul.

Damachi, U.G. 1987, Strategic Factors in Industrial Relations in a Recessionary Economy, In Nigerian Journal of Industrial Relations, Vol.1, № 2 December, Pp10-14

Dublin, R, 1954, Constructive Aspects of Conflict, In Kornhauser A, Dubin R, \& Ross A (Eds) Industrial Conflict, New York: McGraw Hill.

Etuk-Udo, Akanimo, 1999, Returning Professionalism into the Conduct of Industrial Relations, In Human Resources Management; Journal of the Institute of Personnel Management, Vol. 9, No. 3, Pp 19-26

Fashoyin, Tayo, 1984, Incomes and Inflation in Nigeria, Ibadan: Longman Press.

Martens, G.R., 1987, Beyond Politics: New Trends in African Trade Unionism, In Nigerian Journal of Industrial Relations, Vol. 1 (2) December, $\mathrm{Pp}$ 21-25.

Onyeonoru, I. 2001, A Theoretical Diagnosis of Systems Contradictions in Industrial Relations, Ife Social Sciences Review, Vol. 19, No.1. June, Pp 1-13 